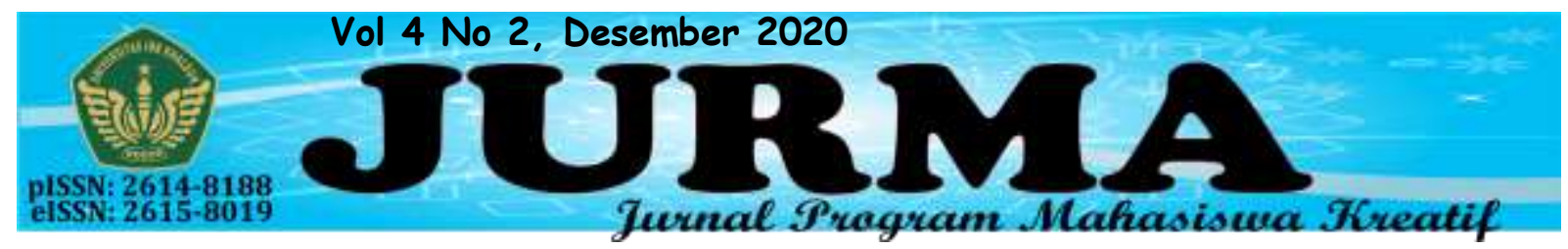

\title{
EDUKASI PHBS VIA DARING PADA REMAJA DIMASA PANDEMI COVID-19
}

\author{
Dewi Indriani ${ }^{1}$ dan Rahma Listyandini ${ }^{2}$ \\ indrianidewi242@gmail.com ${ }^{1}$ \\ listyandini@gmail.com ${ }^{2}$ \\ Fakultas Ilmu Kesehatan Universitas Ibn Khaldun Bogor ${ }^{1,2}$
}

\begin{abstract}
ABSTRAK
Masalah kesehatan seringkali muncul di masyarakat tanpa disadari dan diketahui penyebabnya. Hal tersebut terjadi karena faktor pengetahuan masyarakat yang masih rendah tentang kesehatan di masyarakat. Perilaku hidup bersih dan sehat (PHBS) adalah bentuk perwujudan orientasi hidup sehat dalam budaya perorangan, keluarga, dan masyarakat. Pola hidup sehat seharusnya sudah menjadi kebiasaan baru untuk masyarahat Indonesia di masa Pandemi Covid19 ini. Perilaku hidup bersih dan sehat (PHBS) merupakan upaya preventif pencegahan di masa pandemic covid-19. Pemerintah sudah lama menjalankan program perilaku hidup bersih dan sehat (PHBS) melalui kegiatan promosi kesehatan namun hasilnya belum cukup optimal. Tujuan pengabdian masyarakat adalah untuk meningkatkan pengetahuan dan kesadaran masyarakat terutama para remaja mengenai pentingnya perilaku hidup bersih dan sehat. Metode kegiatan pengabdian kepada masyarakat yang dilaksanakan di desa Leuwisadeng yaitu mengedukasi kesehatan kepada remaja tentang Perilaku Kesehatan Bersih dan Sehat (PHBS). Hasil kegiatan pengabdian masyarakat ini adalah meningkatnya kesadaran masyarakat terutama remaja yang berada di desa leuwisadeng tentang pentingnya perilaku hidup bersih dan sehat pentingnya berolahraga secara teratur, memakan buah-buahan dan sayur sayuran, tidak merokok didalam rumah, menggunakan air bersih serta pentingnya menggunakan jamban sehat.
\end{abstract}

\section{Kata kunci : Perilaku hidup bersih dan sehat, dan remaja}

\section{ABSTRACT}

Health problems often appear in the public unnoticed and known causes. This is because of people's low knowledge about health. Clean and healthy life behavior (PHBS) is a manifestation of healthy orientation in individual, family, and community cultures. The healthful pattern of life should have become a new habit for the good of Indonesia during this covid-19 pandemic. Clean and healthy life behavior (PHBS) is a preventive preventative effort in the appendix covid-19. Governments have long run clean and healthy life behavior programs (PHBS) through health promotion activities, but the results are not optimal. The purpose of community devotion is to increase public knowledge and awareness especially youth about the importance of clean and healthy living behaviors. A method of community service carried out in the village leuwisadeng was educating youth on clean and healthy health behaviors (PHBS). The result of this community's devoted activities is the growing awareness of communities especially youth in leuwisadeng village about the importance of clean living behavior and the 
importance of regular exercise, of eating fruits and vegetables, of not smoking indoors, and the importance of using healthy latrines.

\section{Keywords : clean and healthy living behavior, and teenager}

\section{PENDAHULUAN}

Perilaku Hidup Bersih Dan Sehat (PHBS) merupakan langkah yang harus dilakukan untuk mencapai derajat kesehatan yang optimal bagi setiap orang. Kondisi sehat tidak serta merta terjadi, tetapi harus senantiasa kita upayakan dari tidak sehat menjadi hidup yang sehat serta menciptakan lingkungan yang sehat (MDGs,2015).

Perilaku Hidup Bersih dan Sehat adalah sekumpulan perilaku yang dipraktikan atas dasar kesadaran sebagai hasil pembelajaran yang menjadikan seseorang, keluarga, kelompok atau masyarakat mampu menolong dirinya sendiri (mandiri) di bidang kesehatan dan berperan aktif dalam mewujudkan kesehatan masyarakat (Depkes RI, 2011)

PHBS terdiri dari beberapa indikator khususnya PHBS tatanan institusi pendidikan yaitu, mencuci tangan dengan air yang mengalir dan memakai sabun, mengkonsumsi jajanan atau makanan yang bergizi, menggunakan jamban bersih dan sehat olahraga teratur, memberantas jentik nyamuk, tidak merokok, menimbang berat badan dan mengukur tinggi badan setiap bulan dan membuang sampah pada tempatnya (Sari, 2014).

Masalah kesehatan yang sering timbul pada usia remaja yaitu gangguan perilaku, penyakit infeksi, penyakit saluran pencernaan, penyakit saluran pernafasan, penyakit kulit, penyakit menular dan malnutrisi. Cuci tangan merupakan salah satu solusi yang mudah dan efektif dalam pencegahan penyakit menular dan jajanan yang sehat juga dapat mencegah gangguan saluran pencernaan (Depkes RI, 2015).

Perilaku cuci tangan yang benar merupakan salah satu aspek yang menjadi indikator dalam PHBS yang saat ini menjadi perhatian dunia. Hal ini disebabkan tidak hanya di Negara berkembang, namun juga di Negara maju, masih banyak masyarakat yang lupa melakukan perilaku cuci tangan yang benar. Hal ini menunjukkan masih kurangnya praktek atau tindakan mencuci tangan di masyarakat Anggraini, 2010).

Pola hidup sehat seharusnya sudah menjadi kebiasaan baru untuk masyarahat Indonesia di masa Pandemi Covid-19 ini. Gerakan pola hidup sehat di masyarakat selalu menjadi perhatian bahkan selalu ditingkatkan melalui berbagai program yang dijalankan oleh pemerintah. Program tersebut dinamakan perilaku hidup bersih dan sehat (PHBS). PHBS di kalangan remaja masih belum di pahami oleh masyarakat karena kurangnya informasi yang diterima dan juga kurangnya dukungan fasilitas untuk program tersebut. Bukan hanya itu saja keterbelakangan sosial, ekonomi dan pendidikan menjadi masalah untuk melaksanakan PHBS. Penyebaran virus Korona semakin muncul di kalangan usia remaja.

Mereka umumnya tanpa gejala atau Orang Tanpa Gejala (OTG). Kondisi ini membuat WHO khawatir. Remaja yang terinfeksi tidak memiliki gejala atau gejala ringan. Kondisi itu membuat mereka tanpa sadar menularkan virus ke orang lain. Hal ini dapat meningkatkan risiko penyebaran 
ke orang yang paling rentan, orang tua, orang sakit dalam perawatan jangka panjang.

Masalah kesehatan seringkali muncul di masyarakat tanpa disadari dan diketahui penyebabnya. Hal tersebut terjadi karena faktor pengetahuan masyarakat yang masih rendah tentang kesehatan di masyarakat. Masalah kesehatan tersebut yang sering muncul antara lain masih tingginya angka kematian ibu dan anak, gizi buruk, penyakit menular dan tidak menular, gaya hidup yang tidak sehat dan lain-lain.

Menurut feronika didapatkan hasil berdasarkan pengetahuan tentang PHBS diperoleh hasil bahwa sebagian besar responden memiliki pengetahuan baik sebanyak 48 orang $(55,2 \%)$, pengetahuan cukup sebanyak 26 orang (29,9\%) dan pengetahuan kurang sebanyak 13 orang (14,9\%). Berdasarkan kebiasaan cuci tangan pakai sabun diperoleh hasil sebagian besar dilakukan sebanyak 59 orang $(67,8 \%)$ dan tidak dilakukan sebanyak 28 orang (32.2\%). Hasil tersebut menunjukan bahwa pengetahuan PHBS pada remaja belum $100 \%$ remaja mengetahuinya.

Hasil wawancara pada tanggal 3 September 2020 yang dilakukan pada

\section{METODE}

\section{Waktu dan Tempat Penelitian}

KKN-GTM ini dilaksanakan di desa Leuwisadeng RT 001 RW 001 Kecamatan Leuwisadeng Kab.Bogor, dengan waktu 30 hari dimulai pada tanggal 1 september-30 september 2020.

\section{Sasaran Kegiatan}

Dalam pengabdian masyarakat ini sasaran dari kegiatan adalah para remaja yang berada di wilayah desa Leuwisadeng RT 001 RW 001 Kecamatan Leuwisadeng Kab.Bogor. Responden yang di dapat dari hasil observasi jumlah keseluruhan para remaja di desa leuwisadeng diperoleh informasi 5 dari 10 orang belum mengetahui apa itu PHBS, apa pentinganya PHBS bagi kesehatan di masa Pandemi Covid-19. Adanya permasalahan pada remaja di desa Leuwisadeng RT/RW 001/001 tersebut di karenakan kurangnya informasi mengenai PHBS dan kurangnya tingkat kesadaran pada remaja.

Melalui kegiatan pengabdian kepada masyarakat yang bersinergi dalam program KKN GTM mahasiswa di bidang kesehatan, maka dilaksanakan kegiatan Edukasi Peningkatan Kesehatan Masyarakat Melalui kegiatan PHBS pada remaja dimasa pandemi Covid-19 kegiatan tersebut dilaksanakan dengan sasaran Remaja. Tujuan Kegiatan pengabdian masyarakat ini bertujuan meningkatkan Perilaku hidup bersih dan sehat bagi masyarakar terutama para remaja yang ada di Wilayah Desa Lewisadeng. Manfaat kegiatan ini diharapkan masyarakat dapat menerapkan perilaku hidup bersih dan sehat antara lain: 1) Remaja dapat memahami tentang makanan bergizi. 2). Remaja dapat mempraktekan cuci tangan pakai sabun. 3) Remaja dapat melakukan 3M

remaja di desa Leuwisadeng RT 001 RW 001 yaitu 52 remaja namun, yang bersedia untuk menjadi kader remaja yaitu 12 .

\section{Kegiatan}

Kegiatan pengabdian yang akan dilakukan meliputi beberapa tahapan kegiatan yaitu: 1) Tahap Observasi dan wawancara, 2) Tahap pembentukan program kelompok remaja sehat 3) Tahap evaluasi kegiatan.

Metode Observasi dan Wawancara Melalu Daring 
Kegiatan Observasi awal dan wawancara dilakukan pada tanggal 03 September 2020 Survei Awal dilakukan dengan melihat gambaran permasalahan PHBS pada remaja dan melakukan wawancara via WA (whatsapp) untuk melakukan kajian situasi di bidang kesehatan yang ada di Desa Leuwisadeng, dan mengetahui seberapa besar pengetahuan dan sikap para remaja tersebut untuk berperilaku hidup bersih dan sehat.

\section{Metode Pembentukan Kelompok}

Tahap selanjutnya adalah pembentukan program kelompok remaja sehat, adanya program tersebut bertujuan untuk membekali remaja agar dapat turut andil dalam pencegahan tertularnya Virus Covid-19, sehingga memiliki peningkatan pengetahuan dan juga menjadi volunteer

\section{HASIL DAN PEMBAHASAN}

Berdasarkan hasil observasi dan wawancara, ditemukan: 1). Kurangnya pengetahuan dan informasi pada remaja terkait PHBS karena minimnya pengetahuan tentang kesehatan terutama membahas persoalan PHBS; 2). Kurangnya tingkat kesadaran remaja mengenai PHBS hal itu dikarenakan remaja kurang mengetahui apa manfaat apabila menjalankan PHBS.

\section{Program Pemberdayaan}

Program pemberdayaan masyrakat di Desa Leuwisadeng terbagi menjadi beberapa program yaitu : 1). Program Pembentukan Kader Remaja yang merupakan program utama dari KKN GTM ini, 2). Program edukasi via grup whastapp mengenai PHBS, 3). Program pembagian masker gratis yang merupakan beberapa program pendamping dari KKN GTM. remaja peduli Covid-19. Step program yang akan dijalankan adalah: 1) membentuk kelompok remaja, 2) berdiskusi melalui grup WA, 3) pembekalan menjadi volunteer diantaranya: a. Pengetahuan PHBS, b. Pengetahuan tentang 3M, c. Pembekalan kesehatan sederhana. Kegiatan ini diadakan setiap mingguan berharap para volunteer remaja dapat berperan sebagai pemandu teman yang lain agar dapat mencegah penyebaran virus Covid-19.

\section{Metode Evaluasi}

Kegiatan ketiga selanjutnya adalah evaluasi. Kegiatan evaluasi dilakukan pada bagian akhir rangkaian kegiatan dengan metode pretest dan posttest untuk mengetahui seberapa paham dan mengerti setelah program dijalankan

\section{Program Pembentukan Kader Remaja}

Program utama yang di sebut pembentukan kader remaja merupakan program inti dari kegiatan KKN GTM Fakultas Ilmu Kesehatan Universitas Ibn khaldun Bogor. Program tersebut di lakukan di Desa Leuwisadeng RT 001 RW 001 dengan fokus utama meningkatkan pengetahuan dan kesadaran para remaja mengenai PHBS dan menjadi volunteer remaja dan berperan sebagai pemandu teman yang lain agar dapat mencegah penyebaran virus Covid-19. Kegiatan tersebut dilakukan pada minggu, 20 september 2020.

Apapun Sasaran dari program ini adalah para remaja dengan usia 18-22 tahun, kegiatan ini dibantu oleh dua pemateri. adapun tujuan dari program ini adalah :

1. Menambah pengetahuan para remaja tentang pentingnya perilaku hidup 
bersih dan sehat juga pentingnya menjaga asupa gizi seimbang.

2. Merubah kebiasaan yang belum baik terhadap PHBS dan terhadap pola makannya agar terciptanya kebiasaan baru yang lebih baik.

Pada tahap ini kami melakukan kegiatan dengan mengadakan kelas online dan pelatihan kader remaja dengan tema "AYO BER-PHBS remaja sehat, remaja kuat" Penyelenggaran kelas online melalui via zoom (Daring) dimana para kader dan peserta harus mengikuti dan melakukan pengisian kuesioner preetes dan postets untuk mengetahi pengetahuan peserta sebelum dan sesudah program dijalankan. Dalam program ini peserta dibagi menjadi dua yaitu peserta umum dengan usia 18-22 tahun, dan peserta kader remaja yang terpilih. Adapun topik yang di bahas dalam program ini yaitu :

1. Perilaku hidup bersih dan sehat (PHBS) dan 3M (Mencuci tangan, menjaga jarak dan memakai masker).

2. Gizi Remaja

Di dalam materi ini di jelaskan mengenai bagaimana agar agat tidak terjadinya anemia pada remaja, cara menghitung indeks masa tubuh (IMT), panduan isi piting makan dan lainnya.

Berdasarkan hasil kuesioner pretest yang di lakukan sebelum program di jalankan pada peserta umum menunjukan bahwa pengetahuan peserta umum mengenai PHBS sebesar 61,5\%, peserta yang mengetahui CTPS sebesar 92,3\% dan setelah di lakukan program pengetahuan mengenai PHBS naik menjadi 76,9\% CTPS menjadi $100 \%$ hal itu di lihat dari penilaian posttest. Pada peserta kader remaja menunjukan bahwa pengetahuan peserta mengenai PHBS sebesar 33,3\% dan setelah di lakukan program pengetahuan remaja mengenai PHBS naik menjadi 88,9\%.

\section{Evaluasi Program}

Setelah kami melakukan program intervensi, tahapan selanjutnya adalah monitoring yang bertujuan untuk mengetahui sejauh mana program ini berjalan. secara garis besar dapat berjalan dengan baik, Dari segi pemaparan materi pun sangat cukup. Faktor yang sangat membantu dalam kelancaran kegiatan KKN-GTM ini adalah dukungan serta partisipasi para remaja yang sangat antusias terhadap program kerja tersebut. Namun dalam pelaksanaan kegiatan KKN-GTM mahasiwa juga menemui beberapa kendala yakni, ada beberapa kegiatan yang tertulis di rundown acara yang tidak terlaksana, jaringan sinyal yang kurang memadai, serta kurang nya komunikasi antara peserta dan panitia.

\section{Program kulwap kader remaja}

Program kulwap atau kelas whatsapp dengan tema "Apa itu posyandu remaja" yang di ikuti oleh kader remaja desa Leuwisadeng RT 001 RW 001 merupakan program kelompok dari KKN-GTM ini. Pada program ini kami malakukan kegiatan share materi oleh pemateri dengan cara voice note dan mengirim gambar. Materi ini menjelaskan tentang tujuan posyandu remaja, kegiatan kader remaja dan lainnya. Setelah materi di kirimkan melalu grup whatsapp kita melakukan diskusi dengan melakukan tanya jawab. Dalam program tersebut untuk mengetahui tingkat pengetahuan para kader remaja mengenai posyandu remaja kami melakukan metode pretest dan posttest.

\section{Evaluasi Program}

evaluasi yang di lakukan pada program kelompok ini adalah memastikan kader remaja telah menerima informasi yang di kirimkan melalu grup whatsapp 
dengan cara bertanya di grup atau langsung mengirim pesan kepada sasaran program.

\section{Program Edukasi Via Grup Whatsapp mengenai PHBS}

Program edukasi via grup whatsapp adalah salah satu program pendaming dari KKN-GTM ini. Pada program ini, kami melakukan kegiatan edukasi via grup whatsapp kepada kader remaja di desa Leuwisadeng yang berjumlah 12 orang. Program ini di laksanakan pada tanggal 2125 September 2020 dengan tahap awal pembuatan video dan poster. Pada kegiatan ini kami membuat beberapa video dan poster untuk di sebarkan via grup whatsapp kepada sasaran kita (remaja) video dan poster tersebut menjelaskan mengenai, cara mencuci tangan yang baik dan benar, menjaga jarak (Physical distancing), dan cara memakai masker dan benar. Setelah video dan poster di sebarkan kami melakukan diskusi dengan para kader. Dalam program tersebut untuk mengetahui tingkat pengetahuan para kader remaja mengenai PHBS kami melakukan metode pretest dan posttest. Tujuan dari program tersebut agar para remaja mampu menerapkan protokol kesehatan selama pandemic covid-19.

Berdasarkan hasil kuesioner yang di berikan kepada peserta kader remaja menunjukan bahwa peserta kader remaja yang memakai masker $88,9 \%$ dan setelah di lakukan program tersebut naik menjadi $100 \%$ penilaian tersebut di lihat dari hasil kuesioner pretest dan posttest.

\section{Evaluasi Program}

Monitoring dan evaluasi yang di lakukan pada program pendamping ini adalah memastikan masyarakat sasaran telah menerima informasi yang di kirimkan melalu grup whatsapp dengan cara bertanya di grup atau langsung mengirim pesan kepada sasaran program. Adapun kendala yang di hadapi dari program ini yaitu pada saat melakukan program ada beberapa peserta sasaran yang kurang aktif.

\section{Program pembagian Masker Gratis}

Salah satu program kerja KKN-GTM adalah pembagian masker gratis sebagai wujud dukungan himbauan World Health Organization (WHO) kepada masyarakat desa Leuwisadeng 001/001 yang menghimbau menggunakan masker pada saat keluar rumah. Pembagian masker di lakukan dengan cara door to door atau dari rumah ke rumah untuk menghindari terjadinya kerumunan warga yang dapat menyebabkan kemungkinan besar terjadinya penyebaran covid-19. Dengan adanya pembagian masker gratis ini dapat membantu masyarakat khususnya yang berada di Kecamatan Leuwisadeng RT 001 RW 001 untuk disiplin menggunakan masker ketika beraktivitas di luar rumah.

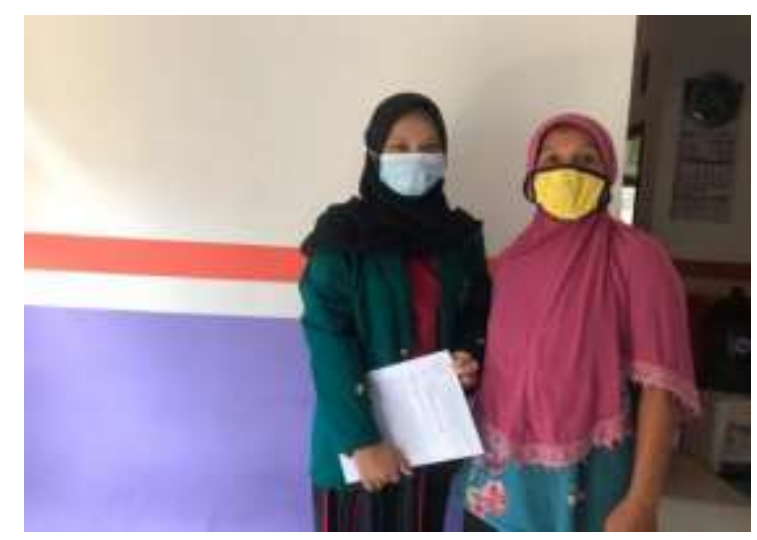

Gambar 1.Izin melakukan kegiatan kepada ibu RT 


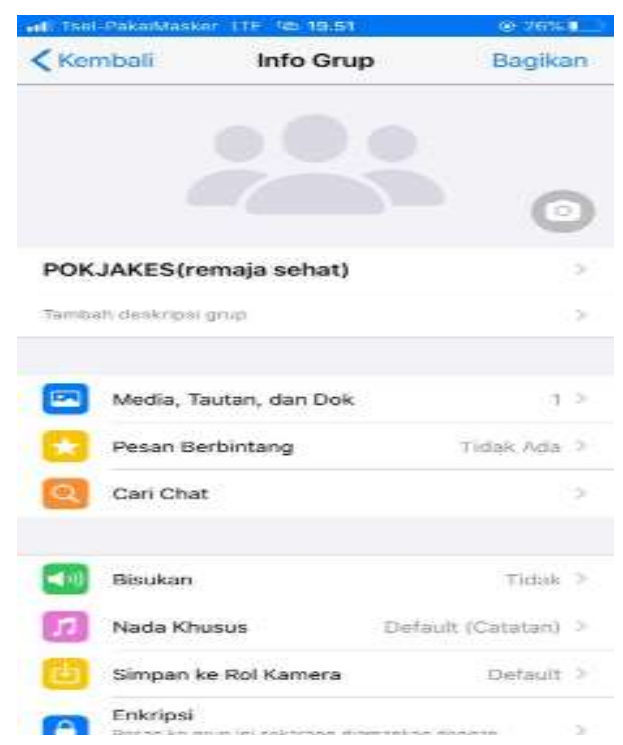

Gambar 2. Pembentukan Grup whatsapp remaja sehat

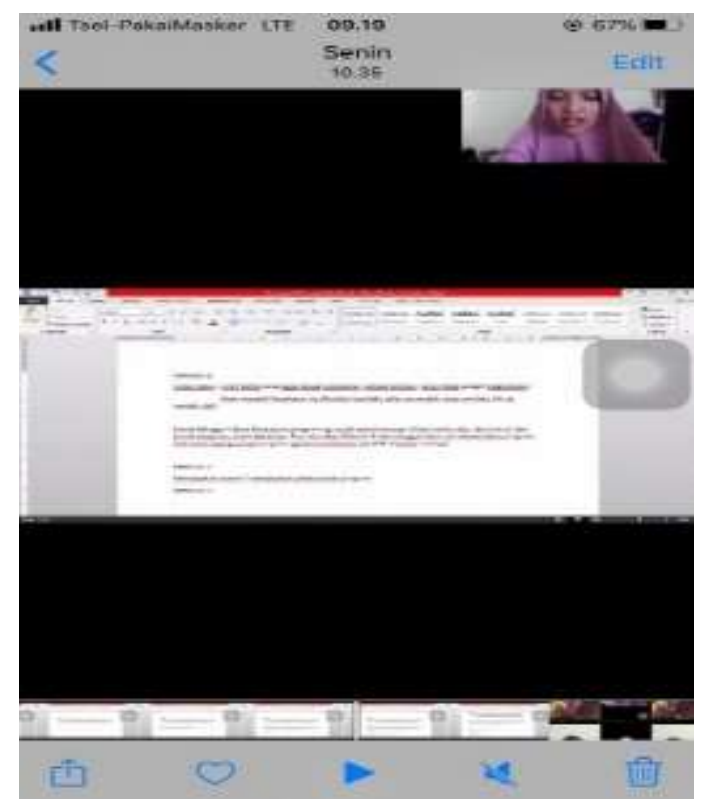

Gambar 3. Melakukan kegiatan via zoom bersama DPL

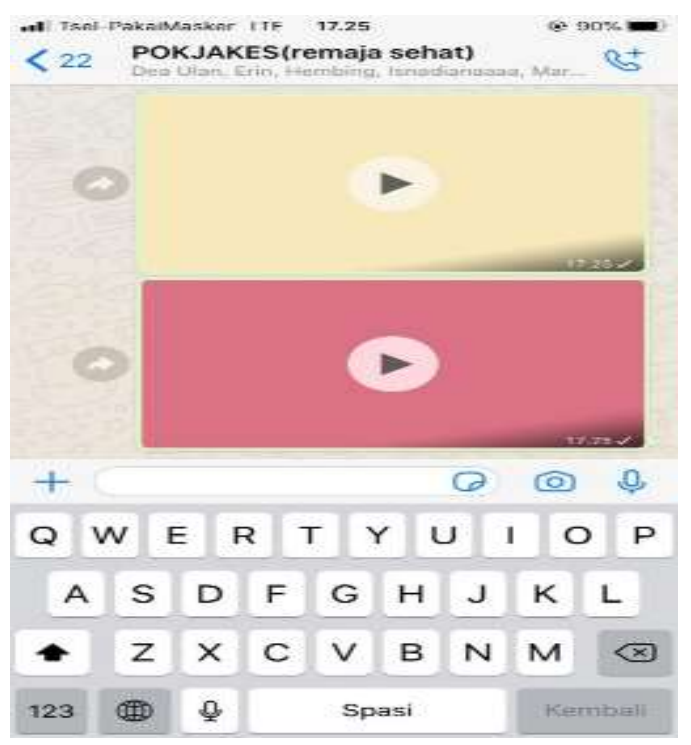

Gambar 4. Edukasi video lewat grup whatsapp

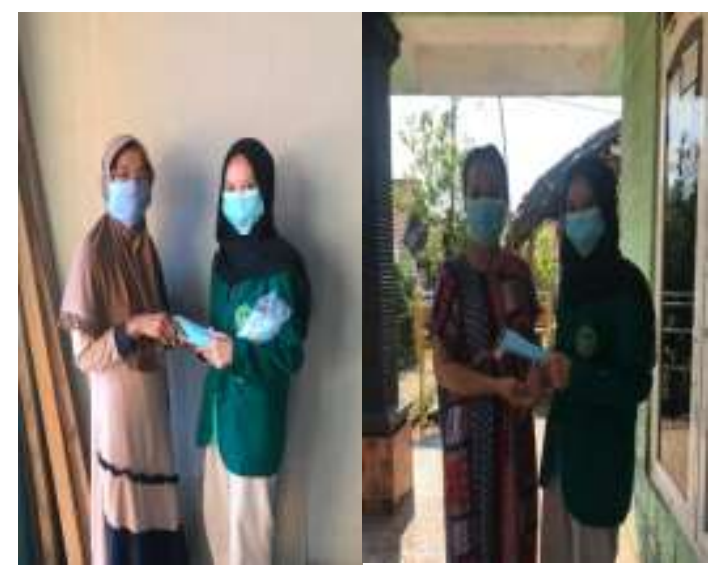

Gambar 6. Pemberian maker gratis

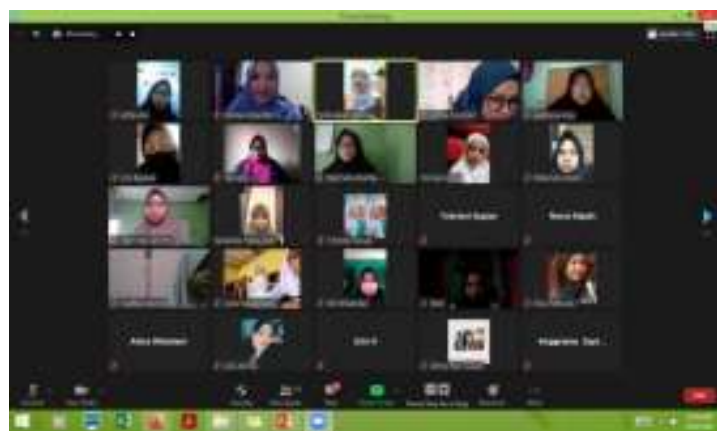

Gambar 5. Kegiatan kelas online bersama peserta dan kader remaja 


\section{KESIMPULAN DAN SARAN}

Berdasarkan hasil kuesioner pretest yang di lakukan sebelum program di jalankan pada peserta umum menunjukan bahwa pengetahuan peserta umum mengenai PHBS sebesar 61,5\%, peserta yang mengetahui CTPS sebesar 92,3\% dan setelah di lakukan program pengetahuan mengenai PHBS naik menjadi 76,9\% CTPS menjadi $100 \%$ hal itu di lihat dari penilaian posttest.

Pada peserta kader remaja menunjukan bahwa pengetahuan peserta kader remaja mengeai PHBS sebesar 33,3\% dan setelah di lakukan program pengetahuan remaja mengenai PHBS naik menjadi $88,9 \%$. Hal tersebut membuktikan bahwa program Edukasi PHBS Via Daring

\section{DAFTAR PUSTAKA}

Feronika, Dewi. 2018. Hubungan antara pengetahuan remaja tentang perilaku hidup bersih dan sehat (PHBS) di sekolah dengan kebiasaan cuci tangan paki sabun (CTPS) di SMP Negeri 7 Samarinda.

Islamiyati, Nur. 2014. Pengaruh pemberdayaan peer group terhadap perilaku hidup bersih dan sehat pada anak SDN 1 Kasihan Ngentakrejo Lendah Kulon Progo. Skripsi : Sekolah Tinggi Ilmu Kesehatan Aisyiyah Yogyakarta.

Skripsi: Universitas Muhammadiyah Kalimantan Timur

Sari, Indriani Dkk 2016. Faktor-faktor yang berhubungan dengan perilaku hidup
Pada Remaja Dimasa Pandemi Covid-19 berhasil membuat para remaja menjadi dapat memahami tentang makanan bergizi, Remaja dapat mempraktekan cuci tangan pakai sabun. Remaja dapat melakukan 3M

Kegiatan ini diharapkan dapat dijadikan acuan untuk penelitian selanjutnya, guna meningkatkan kualitas penelitian tentang PHBS, penulis berharap peneliti selanjutnya dapat lebih komprehensif lagi dalam melakukan penelitiannya. Dan dengan adanya berbagai media yang mendukung informasi terkait PHBS pada remaja dapat menjaga kesehatan pada masa pandemic Covid-19 ini.

bersih dan sehat sebagai upaya untuk pencegahan penyakit diare pada siswa di SDN Karang Towo Kecamatan Karang Tengah Kabupaten Demak. Jurnal kesehatan masyarkat Vol.4 No. 3 Universitas Diponegoro.

Tentama, Fatma. 2017. Penerapan perilaku hidup bersih dan sehat (PHBS) demi kesejahteraan masyarakat kecamatan tuntang kabupaten semarang jawa tengah. Jurnal pemberdayaan masyarakat Universitas Ahmad Dahlan Yogyakarta.

Octa, Audria 2019. Hubungan pengetahuan dan sikap terhadap perilaku cuci tangan pada masyarkat kelurahan pegiria. Jurnal Promkes Vol.7 No.1 2019 Universitas Airlangga Surabaya 